\title{
Evaluation of seasonal atmosphere-biosphere exchange estimations with TCCON measurements
}

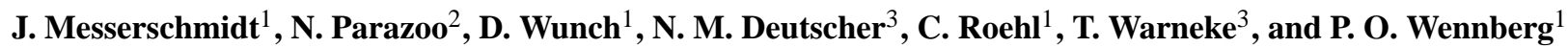 \\ ${ }^{1}$ California Institute of Technology, Pasadena, CA, USA \\ ${ }^{2}$ Jet Propulsion Laboratory, Pasadena, CA, USA \\ ${ }^{3}$ Institute of Environmental Physics, Bremen, Germany
}

Correspondence to: J. Messerschmidt (janina@ caltech.edu)

Received: 30 April 2012 - Published in Atmos. Chem. Phys. Discuss.: 22 May 2012

Revised: 20 March 2013 - Accepted: 8 April 2013 - Published: 17 May 2013

\begin{abstract}
We evaluate three estimates of the atmospherebiosphere exchange against total column $\mathrm{CO}_{2}$ observations from the Total Carbon Column Observing Network (TCCON). Using the GEOS-Chem transport model, we produce forward simulations of atmospheric $\mathrm{CO}_{2}$ concentrations for the 2006-2010 time period using the Carnegie-AmesStanford Approach (CASA), the Simple Biosphere ( $\mathrm{SiB}$ ) and the GBiome-BGC models. Large differences in the $\mathrm{CO}_{2}$ simulations result from the choice of the atmosphere-biosphere model. We evaluate the seasonal cycle phase, amplitude and shape of the simulations. The version of CASA currently used as the a priori model by the GEOS-Chem carbon cycle community poorly represents the season cycle in total column $\mathrm{CO}_{2}$. Consistent with earlier studies, enhancing the $\mathrm{CO}_{2}$ uptake in the boreal forest and shifting the onset of the growing season earlier significantly improve the simulated seasonal $\mathrm{CO}_{2}$ cycle using CASA estimates. The $\mathrm{SiB}$ model gives a better representation of the seasonal cycle dynamics. The difference in the seasonality of net ecosystem exchange (NEE) between these models is not the absolute gross primary productivity (GPP), but rather the differential phasing of ecosystem respiration (RE) with respect to GPP between these models.
\end{abstract}

\section{Introduction}

An accurate estimation of carbon fluxes is a central goal of the carbon cycle community. Such estimates have been derived on small spatial scales using direct measures of the fluxes via eddy-covariance (e.g., FLUXNET, 2013) and by carbon stock analysis (e.g., Gaudinski et al., 2000; Goodale et al., 2002). On larger spatial scales, inverse methods have been attempted using measurements of the spatial and temporal variations in atmospheric $\mathrm{CO}_{2}$ concentrations (e.g., Baker et al., 2006; Peters et al., 2007; Michalak et al., 2004).

Traditionally, atmospheric inverse modeling has used observations from a global network of in situ boundary layer measurement stations. However, the substantial impact of synoptic scale weather systems (e.g., 3-10 days) in driving local variability in atmospheric $\mathrm{CO}_{2}$ has been illustrated in recent studies (e.g., Keppel-Aleks et al., 2011; Parazoo et al., 2008). Meridional advection produces significant local variability in atmospheric $\mathrm{CO}_{2}$ during summertime in the Northern Hemisphere, when there are strong north-south gradients in $\mathrm{CO}_{2}$. Hence, large-scale errors in the a priori flux distribution can alias into errors at local scales, generally yielding local/regional flux variability that is too large.

Total column measurements are expected to provide improved large-scale constraints on carbon cycle processes (Rayner and O'Brien, 2001; Yang et al., 2007) because variations in total column are dominated by hemispheric-scale flux rather than local and regional fluxes (Keppel-Aleks et al., 2012). Hence, total column measurements act as an extension of the in situ continental boundary layer network, which provides excellent constraints at local and regional scales. Keppel-Aleks et al. (2012) estimated the north-south $\mathrm{CO}_{2}$ gradient using total column measurements from the TCCON by correlating the $\mathrm{CO}_{2}$ abundances to the mid-tropospheric potential temperature, which serves as a dynamical tracer 
Table 1. Fluxes used in the GEOS-Chem $\mathrm{CO}_{2}$ simulation. The inventories, a short description and references are listed as in Nassar et al. (2010).

\begin{tabular}{|c|c|c|c|}
\hline Flux & Inventory & Description & References \\
\hline Fossil fuel emissions & CDIAC & $\begin{array}{l}\text { (Carbon Dioxide Information Analysis Cen- } \\
\text { ter), Year-specific monthly averaged fossil fuel } \\
\text { emissions, 2008-2010 scaled with CDIAC } \\
2007 \text { data }\end{array}$ & $\begin{array}{l}\text { Andres et al. (1996); } \\
\text { Boden et al. (2009); } \\
\text { Le Quere et al. (2009) }\end{array}$ \\
\hline Fire emissions & $\begin{array}{l}\text { GFED } \\
(\mathrm{v} .2)\end{array}$ & $\begin{array}{l}\text { (Global Fire Emissions Database), 8-day data } \\
(2001-2007)\end{array}$ & \\
\hline Biofuel emissions & & & Yevich and Logan (2003) \\
\hline $\begin{array}{l}\text { Balanced ecosystem } \\
\text { exchange }\end{array}$ & CASA & $\begin{array}{l}\text { 3-hourly Net Ecosystem Production (NEP), } \\
\text { (balanced - no net annual flux) }\end{array}$ & $\begin{array}{l}\text { Potter et al. (1993); } \\
\text { Olsen and Randerson } \\
(2004)\end{array}$ \\
\hline Net ecosystem uptake & $\begin{array}{l}\text { TransCom } \\
\text { climatol- } \\
\text { ogy }\end{array}$ & $\begin{array}{l}-5.29 \mathrm{PgC} \mathrm{yr}^{-1} \text { (adjusted for biomass/biofuel } \\
\text { burning) }\end{array}$ & Baker et al. (2006) \\
\hline Ocean exchange & & $\begin{array}{l}\text { Monthly ocean flux climatology of non-El Nino } \\
\text { years }\end{array}$ & Takahashi et al. (2009) \\
\hline Ship emissions & ICOADS & $\begin{array}{l}\text { (International Comprehensive Ocean Atmo- } \\
\text { sphere Data Set), International ship } \mathrm{CO}_{2} \text { emis- } \\
\text { sions with monthly variability scaled to annual } \\
\text { values for 1985-2006 }\end{array}$ & $\begin{array}{l}\text { Corbett and Koehler } \\
(2003,2004) \text {; Wang et al. } \\
(2007) \text {; Endresen et al. } \\
(2007)\end{array}$ \\
\hline Plane emissions & SAGE & $\begin{array}{l}\text { (System for assessing Aviations Global Emis- } \\
\text { sions), Aviation emission 3-D distribution from } \\
\text { fuel burning, scaled to annual } \mathrm{CO}_{2} \text { values for } \\
1985-2002 \text { and estimates for } 2002-2009 \text {. }\end{array}$ & $\begin{array}{l}\text { Sausen and Schumann } \\
\text { (2000); Kim et al. (2005, } \\
\text { 2007); Wilkerson et al. } \\
\text { (2010) }\end{array}$ \\
\hline
\end{tabular}

for synoptic-scale dynamics. Consistent with the findings of Randerson et al. (1997), the authors showed that the seasonal $\mathrm{CO}_{2}$ cycle seen at four Northern Hemisphere TCCON sites is dominated by the NEE in the boreal forest and the temporal phase of the uptake. The $\mathrm{CO}_{2}$ fields were simulated with a general circulation model (GCM) and the NEE was estimated by the CASA model. Increasing the NEE by $40 \%$ between $45-65^{\circ} \mathrm{N}$ and initiating the growing season one month earlier in the model significantly improved the $\mathrm{CO}_{2}$ seasonal cycle.

Here, we evaluate three a priori NEE flux distributions with total column measurements using the GEOS-Chem global three-dimensional (3-D) chemical transport model (CTM) driven by year-specific meteorological input data. The NEE is defined in this work as follows: a net $\mathrm{CO}_{2}$ flux from the ecosystem to the atmosphere is positive and referred to as net $\mathrm{CO}_{2}$ release. A net $\mathrm{CO}_{2}$ flux from the atmosphere to the ecosystem is negative and referred to as net $\mathrm{CO}_{2}$ uptake. We analyze the following atmosphere-biosphere exchange inventories: the Carnegie-Ames-Stanford Approach (CASA, Olsen and Randerson, 2004, described in Sect. 3), the Simple Biosphere model (SiB, Baker et al., 2003, described in Sect. 4) and the GBiome-BGC model (Trusilova and Churkina, 2008, described in Sect. 5). The $\mathrm{CO}_{2}$ total column abundances from these model runs are compared with measured columns from the TCCON
(Sect. 7). The GEOS-Chem model and TCCON observations are described in Sects. 2 and 6, respectively. Additionally, we investigate a simulation with CASA, but with uptake enhanced in the boreal forest and with the onset of the growing season shifted according to Keppel-Aleks et al. (2012) (Sect. 7). Dynamic NEE in SiB is evaluated in Sect. 7.3.

\section{GEOS-Chem $\mathrm{CO}_{2}$ simulation}

GEOS-Chem is a global 3-D chemical transport model for atmospheric composition driven by meteorological input data from the Goddard Earth Observing System (GEOS) of the NASA Global Modeling and Assimilation Office to simulate global atmospheric composition, including $\mathrm{CO}_{2}$ (Bey et al., 2001). Estimates of $\mathrm{CO}_{2}$ fluxes due to fossil fuel emissions, ocean-atmosphere exchange and biosphere-atmosphere exchange are provided by inventories and atmospheric inverse models. In the standard version of the GEOS-Chem $\mathrm{CO}_{2}$ simulation, described by Nassar et al. (2010), climatological NEE from the CASA model are used to estimate the balanced atmosphere-biosphere exchange (Olsen and Randerson, 2004).

In this study, we use GEOS-Chem version v9-01-01 with the GEOS-5 fields, and a spatial resolution of $2^{\circ} \times 2.5^{\circ}$ (latitude $\times$ longitude) with 47 vertical layers. The $\mathrm{CO}_{2}$ simulation relies on the inventories listed in Table 1 and the trend in 
$\mathrm{CO}_{2}$ is determined by the sum of these sources and sinks. The $\mathrm{CO}_{2}$ simulations were started with restart files provided by the GEOS-Chem team (starting on the 1st of January 2005), allowing one year spin-up for the time period 2006-2010.

In GEOS-Chem, the NEE consists of two components: the first component is the total net yearly uptake, based on the TransCom climatology and approximated by $-5.29 \mathrm{PgC} \mathrm{yr}^{-1}$ (Baker et al., 2006) (Table 1: "Net ecosystem uptake"). The second component is the NEE without the net yearly $\mathrm{CO}_{2}$ uptake: the balanced NEE, which drives the seasonal $\mathrm{CO}_{2}$ cycle (Table 1: "Balanced ecosystem exchange"). This balanced NEE is the focus of this study and in the following sections referred to as NEE. The three NEE models examined in this study are described in the following sections.

\section{CASA}

The CASA model is the standard biosphere model input to the GEOS-Chem $\mathrm{CO}_{2}$ simulations. Even though, CASA was designed to have interannually varying fluxes, it is implemented as climatological NEE within GEOS-Chem. Climatological (year 2000) three hourly NEE fields are computed from the difference between GPP and RE. Monthly GPP data with a $1^{\circ} \times 1^{\circ}$ spatial resolution are defined as two times the net primary production (NPP) derived with the CASA model and scaled to $5.5^{\circ} \times 5.5^{\circ}$ grid boxes. The monthly GPP values are distributed with shortwave radiation flux data from the National Center for Environmental Prediction (NCEP, Kalnay et al., 1996) data assimilation model for the year 2000 to three hourly values. Monthly respiration data are calculated with NCEP temperature data for the year 2000 at $5.5^{\circ} \times 5.5^{\circ}$ grid boxes and also interpolated to $3 \mathrm{~h}$ intervals (Olsen and Randerson, 2004; Potter et al., 1993). The GEOSChem $\mathrm{CO}_{2}$ simulation uses the CASA NEE interpolated to the $2^{\circ} \times 2.5^{\circ}$ GEOS-Chem grid. Hence, the standard NEE is based on data derived for the year 2000, and GEOS-Chem a priori biosphere fluxes do not have interannual variability.

\section{$4 \mathrm{SiB}$}

The SiB model parameterizes land surface biophysical processes and ecosystem metabolism (Sellers et al., 1986, 1996; Denning et al., 1996). We use three hourly reanalysis data of air temperature, pressure, humidity, wind speed, radiation and precipitation from the Modern-Era Retrospective analysis for Research Applications (MERRA) (Rienecker et al., 2011) to drive the model for years 2006 through 2010. Fire emissions are accounted for by using GFED2 (Global Fire Emissions Database) data (e.g., Baker et al., 2010). Model parameters are determined using a combination of satellite data, literature values and standard $\mathrm{SiB}$ parameters (Sellers et al., 1996). The $\mathrm{SiB}$ surface fluxes are calculated at $1^{\circ} \times 1.25^{\circ}$ spatial resolution, saved as three hourly averages and scaled to the $2^{\circ} \times 2.5^{\circ}$ GEOS-Chem grid. The SiB NEE estimations are nearly balanced (net yearly uptake of about $-0.07 \mathrm{Pg} \mathrm{yr}^{-1}$ ). In this study, we use both climatological (year 2009) and dynamical fluxes driven by both surface temperature changes and changes in phenology. Further details on the SiB NEE simulations are given in Parazoo et al. (2008).

\section{GBiome-BGC}

GBiome-BGC (version 1) is based on the BIOME-BGC numerical ecosystem model (v. 4.1.1), but is designed for global simulations (Trusilova and Churkina, 2008). BIOME-BGC is a numerical model designed for point studies in forests. It simulates water storage and fluxes, and carbon and nitrogen storage. It is parameterized for seven different types of ecosystems. The Numerical Terradynamic Simulation Group (NTSG) at the University of Montana, USA, stores and updates code versions of BIOME-BGC for public release (http: //www.ntsg.umt.edu/).

Daily averaged meteorological fields from the NCEP are used to derive year-specific NEE data with a $1^{\circ} \times 1^{\circ}$ spatial resolution. To modulate a diurnal $\mathrm{CO}_{2}$ cycle, 3-hourly balanced NEE data are derived by distributing the daily GPP output per grid cell according to the solar zenith angle, whereas the respiration is linearly interpolated (Rödenbeck, 2005). Here, we use climatological fluxes (year 2009), scaled to the $2^{\circ} \times 2.5^{\circ}$ GEOS-Chem grid. The GBiome-BGC NEE estimations are not balanced, and have a net yearly uptake of $-0.705 \mathrm{Pg} \mathrm{yr}^{-1}$. Therefore, the GEOS-Chem $\mathrm{CO}_{2}$ simulations using the GBiome-BGC NEE estimations are detrended to compensate for the net yearly uptake.

\section{TCCON}

The TCCON is a worldwide network of ground-based Fourier transform spectrometers (FTSs) that was founded in 2004 (Washenfelder et al., 2006). TCCON data products are column-averaged dry-air mole fractions, e.g., $\mathrm{X}_{\mathrm{CO}_{2}}, \mathrm{X}_{\mathrm{CH}_{4}}$, $\mathrm{X}_{\mathrm{N}_{2} \mathrm{O}}, \mathrm{X}_{\mathrm{CO}}$ (Wunch et al., 2011a). TCCON has been largely used as a calibration and validation resource for satellite measurements (e.g., Buchwitz et al., 2006; Barkley et al., 2007; Butz et al., 2011; Morino et al., 2011; Reuter et al., 2011; Wunch et al., 2011b; Schneising et al., 2012) and provided insights into carbon cycle science (e.g., Yang et al., 2007; Chevallier et al., 2011; Keppel-Aleks et al., 2012). The individual TCCON sites are operated by various institutions around the world (e.g., Washenfelder et al., 2006; Deutscher et al., 2010; Geibel et al., 2010; Messerschmidt et al., 2011; Wunch et al., 2011a). Here, TCCON $\mathrm{X}_{\mathrm{CO}_{2}}$ data (version GGG2009) are used to analyze the influence of the three different NEE estimations on the GEOS-Chem $\mathrm{CO}_{2}$ simulation. The TCCON $\mathrm{X}_{\mathrm{CO}_{2}}$ data have a precision better than $0.25 \%(\sim 1 \mathrm{ppm})(1 \sigma)$ (Wunch et al., 2011a), under clear 
Table 2. TCCON sites (latitude, longitude and altitude). The data record time period and references are listed.

\begin{tabular}{lcrrll}
\hline Site & $\begin{array}{c}\text { Lat. } \\
{\left[{ }^{\circ} \mathrm{N}\right]}\end{array}$ & $\begin{array}{r}\text { Long. } \\
{\left[{ }^{\circ} \mathrm{E}\right]}\end{array}$ & $\begin{array}{r}\text { Alt. } \\
{[\mathrm{m} \text { a.s.1.] }}\end{array}$ & $\begin{array}{l}\text { Data record } \\
{[\text { date] }}\end{array}$ & References \\
\hline Białystok, Poland & 53.23 & 23.03 & 180 & since March 2009 & Messerschmidt et al. (2012) \\
Bremen, Germany & 53.10 & 8.85 & 5 & since March 2005 & \\
Lamont, Oklahoma & 36.60 & -97.49 & 320 & since July 2008 & \\
Park Falls, Wisconsin & 45.95 & -90.27 & 442 & since April 2004 & Washenfelder et al. (2006) \\
\hline
\end{tabular}

sky conditions, though $0.1 \%(1-\sigma)$ precision can be achieved (Washenfelder et al., 2006; Deutscher et al., 2010; Messerschmidt et al., 2010). Here, $\mathrm{X}_{\mathrm{CO}_{2}}$ measurements at Bremen (Germany), Białystok (Poland), Lamont (Oklahoma) and Park Falls (Wisconsin) are used. The Park Falls and Bremen sites have the longest data records, covering the whole time period from 2006 to 2010. Measurements at Lamont started in July 2008 and in Białystok in March 2009. The data density is dependent on whether the TCCON instrument performs measurements automatically (Park Falls, Lamont and Białystok) and on the weather conditions at the site. Long time periods without measurements indicate major instrument failures. The numbers of days averaged in the analyses are given in Table S1 in the Supplement. All sites were calibrated to World Metereological Organization (WMO) standards through high altitude aircraft campaigns (Wunch et al., 2010; Messerschmidt et al., 2011) and are further introduced in Table 2.

To compare the GEOS-Chem $\mathrm{CO}_{2}$ profile data with the TCCON data, we integrate the profiles to yield columnaveraged $\mathrm{CO}_{2}$ dry-air mole fractions. For each TCCON measurement, the daily averaged GEOS-Chem $\mathrm{CO}_{2}$ simulation profile for the same day was smoothed with the averaging kernel and a priori profile from the TCCON measurement

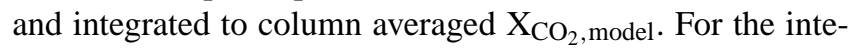
gration, we use the NCEP pressure, altitude, temperature and $\mathrm{H}_{2} \mathrm{O}$ profile, interpolated to the location of the TCCON station and to local noon (Wunch et al., 2011a).

\section{GEOS-Chem $\mathrm{CO}_{2}$ simulations with different NEE estimations}

The NEE estimations of the three models, CASA, GBiomeBGC (both climatological) and $\mathrm{SiB}$ (year-specific), are shown in Fig. 1. In the upper panel, the latitudinal NEE distributions, integrated for the months May to August, are depicted. The large seasonally varying NEE in boreal forests (between $45^{\circ}$ and $65^{\circ} \mathrm{N}$ ) is evident in all three models. The largest difference between the models can also be found in this region. Both $\mathrm{SiB}$ and GBiome-BGC exhibit a larger sink during summer than CASA by up to $40 \%$.

In the bottom panel of Fig. 1, the time series of the monthly NEE integrated over all grid points between $30^{\circ} \mathrm{N}$ and $90^{\circ} \mathrm{N}$ are compared. The time series reflect the differences al- ready seen in the latitudinal NEE distributions: the more pronounced summer sink in both $\mathrm{SiB}$ and GBiome-BGC leads to a larger seasonal cycle amplitude than in CASA. The winter NEE peak is different in all three models: in January, CASA shows a dip, in contrast to the maximum in GBiome$\mathrm{BGC}$ and the slightly earlier maximum in $\mathrm{SiB}$. The $\mathrm{CO}_{2}$ drawdown starts in April in GBiome-BGC and SiB, and is shifted one month later in CASA. The autumn release occurs simultaneously in $\mathrm{SiB}$ and CASA, and about a month earlier in GBiome-BGC. These differences lead to a broader seasonal cycle minimum in $\mathrm{SiB}$ compared with CASA and GBiome-BGC.

\subsection{Evaluating GEOS-Chem $\mathrm{CO}_{2}$ simulations with TCCON measurements}

The differences in the $\mathrm{CO}_{2}$ simulations using these different NEE inputs are illustrated in Fig. 2 (The $\mathrm{CO}_{2}$ simulation using manipulated CASA NEE (CASA early_i40) is discussed in Sect. 7.2). The monthly averages are compared to the mean of the monthly averages of the $\mathrm{X}_{\mathrm{CO}_{2}}$ time series at the four TCCON sites. The amplitude and phase of the simulated seasonal $\mathrm{CO}_{2}$ cycle is dominated by the differences in the NEE estimations (Fig. 1). The drawdown starts about a month earlier using $\mathrm{SiB}$ or GBiome-BGC, compared with the CASA input. The largest drawdown is found for the $\mathrm{SiB} \mathrm{NEE}$ and the smallest using the CASA NEE. The period when $\mathrm{CO}_{2}$ declines is longest for $\mathrm{SiB}$ and shortest for CASA. The comparison with the TCCON measurements reveals an underestimation of the seasonal amplitude for the simulations using GBiome-BGC and CASA and an overestimation by SiB. Using CASA, the start of the growing season is delayed for all years. The start of the growing season in $\mathrm{SiB}$ and GBiomeBGC is in relatively good agreement with the TCCON data.

In order to analyze the general patterns, the monthly means of the five years were averaged to give a mean seasonal cycle for each NEE input as well as for the TCCON data (Fig. 3). The start of the $\mathrm{CO}_{2}$ drawdown in spring and the start of the $\mathrm{CO}_{2}$ release in autumn are estimated by the zero crossing times of the seasonal $\mathrm{CO}_{2}$ cycle, indicated by dots in Fig. 3 . (The seasonal $\mathrm{CO}_{2}$ cycles are shifted to have a mean of zero). The delay of the onset and the end of the growing season are calculated by the time lag between the zero crossing times of the simulated seasonal $\mathrm{CO}_{2}$ cycle and the zero crossing times of the TCCON time series. For the GEOS-Chem 
Table 3. Analysis of the GEOS-Chem $\mathrm{CO}_{2}$ simulations using different NEE estimations. Correlation coefficients for GEOS-Chem $\mathrm{CO}_{2}$ simulations with TCCON measurements for the CASA inventory (standard/manipulated), year-specific SiB fluxes and $\mathrm{SiB}$ climatology.

\begin{tabular}{|c|c|c|c|c|c|}
\hline & CASA & $\mathrm{SiB}$ & $\begin{array}{l}\text { GBiome- } \\
\text { BGC }\end{array}$ & $\begin{array}{l}\text { manipulated } \\
\text { CASA }\end{array}$ & $\begin{array}{c}\mathrm{SiB} \\
2009 \\
\mathrm{NEE}\end{array}$ \\
\hline $\mathrm{CO}_{2}$ drawdown time delay [days] & $10 \pm 1$ & $-6 \pm 1$ & $-16 \pm 1$ & $-1 \pm 1$ & - \\
\hline $\mathrm{CO}_{2}$ release time delay [days] & $-3 \pm 1$ & $9 \pm 1$ & $9 \pm 1$ & $2 \pm 1$ & - \\
\hline $\begin{array}{l}\text { cross correlation between } \\
\text { the seasonal cycles [days] }\end{array}$ & $-4 \pm 1$ & $0 \pm 1$ & $4 \pm 1$ & $0 \pm 1$ & - \\
\hline $\begin{array}{l}\text { scaling factor fitting the } \\
\text { seasonal amplitude [a.u.] }\end{array}$ & 0.85 & 1.09 & 0.88 & 1.20 & - \\
\hline correlation coefficient & 0.954 & 0.971 & - & 0.963 & 0.970 \\
\hline
\end{tabular}

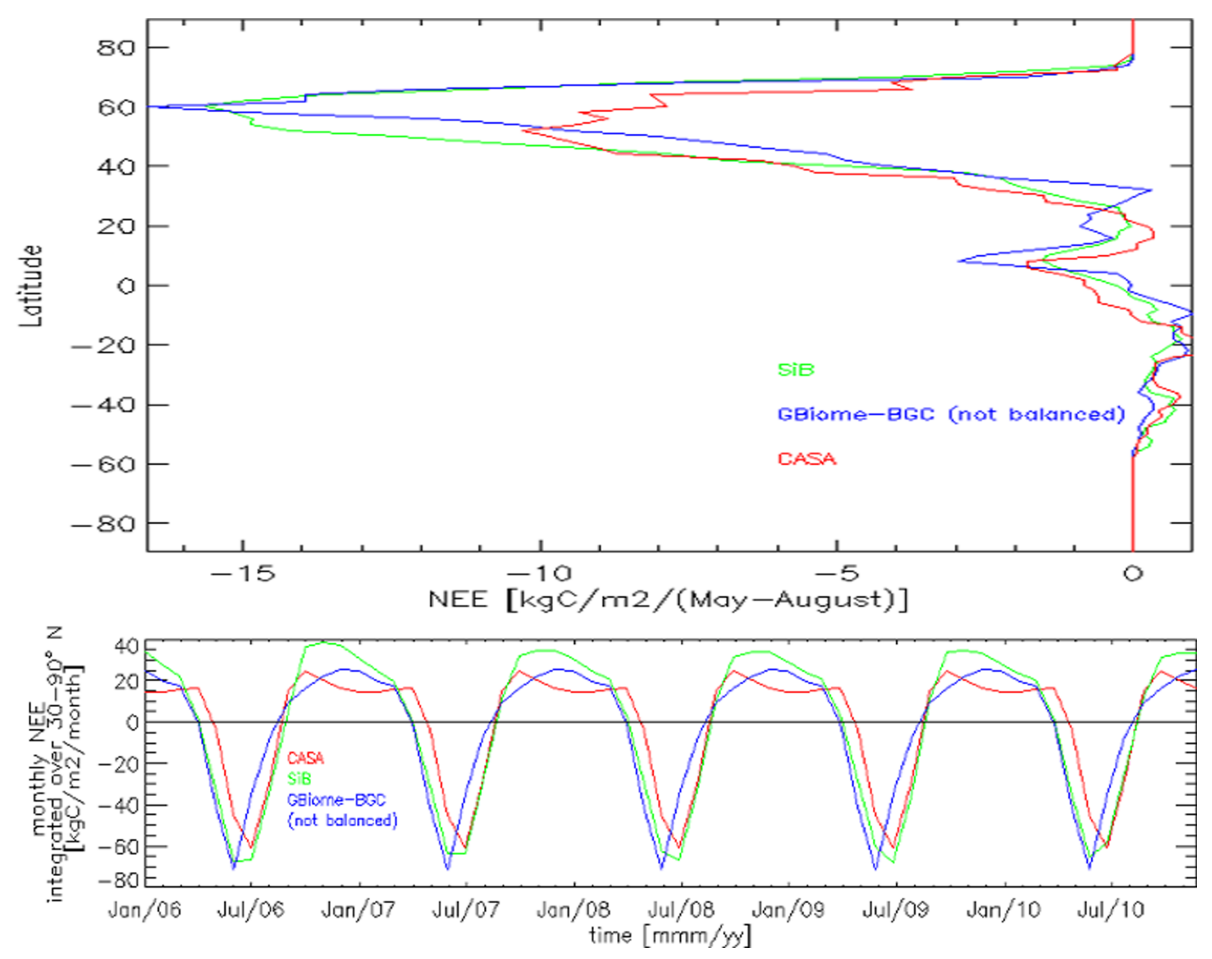

Fig. 1. Upper panel: latitudinal NEE distributions integrated for May until August. The sink between $45^{\circ}$ and $65^{\circ} \mathrm{N}$ reflects the $\mathrm{CO}_{2}$ uptake in the boreal forest in all three models and the biggest differences between the models are found here as well. CASA has a less distinct sink than SiB and GBiome-BGC. Bottom panel: the time series of monthly NEE integrated between $30-90^{\circ} \mathrm{N}$. The SiB NEE estimates include dynamical fluxes while the CASA and GBiome-BGC fluxes used here are climatological.

$\mathrm{CO}_{2}$ simulation using $\mathrm{SiB}$ or GBiome-BGC, the $\mathrm{CO}_{2}$ drawdown starts too early (with a lag of -6 days \pm 1 day and -16 days \pm 1 day, respectively), whereas the standard CASA NEE inventory leads to a delay in the $\mathrm{CO}_{2}$ drawdown (by +10 days \pm 1 day). In contrast, the $\mathrm{CO}_{2}$ release is estimated to be too early using the CASA inventory (by -3 days \pm 1 day), but is delayed using $\mathrm{SiB}$ or GBiome-BGC NEE inputs (by +9 days \pm 1 day for both models). The time lags in days are given in Table 3 as well.
This estimation of the $\mathrm{CO}_{2}$ drawdown and release relies only on the zero crossing times. The entire seasonal cycle shape can be evaluated in a cross correlation of the modeled $\mathrm{X}_{\mathrm{CO}_{2}}$ and the measured TCCON $\mathrm{X}_{\mathrm{CO}_{2}}$. The cross correlation is a measure of the similarity of two waveform patterns as a function of a time shift applied to one waveform. The cross correlation of the GEOS-Chem $\mathrm{CO}_{2}$ simulation infers a time shift of -4 days \pm 1 day for CASA and +4 days \pm 1 day for GBiome-BGC. The simulation using SiB is optimized without shifting. The time shifts in days are also listed in Table 3. 


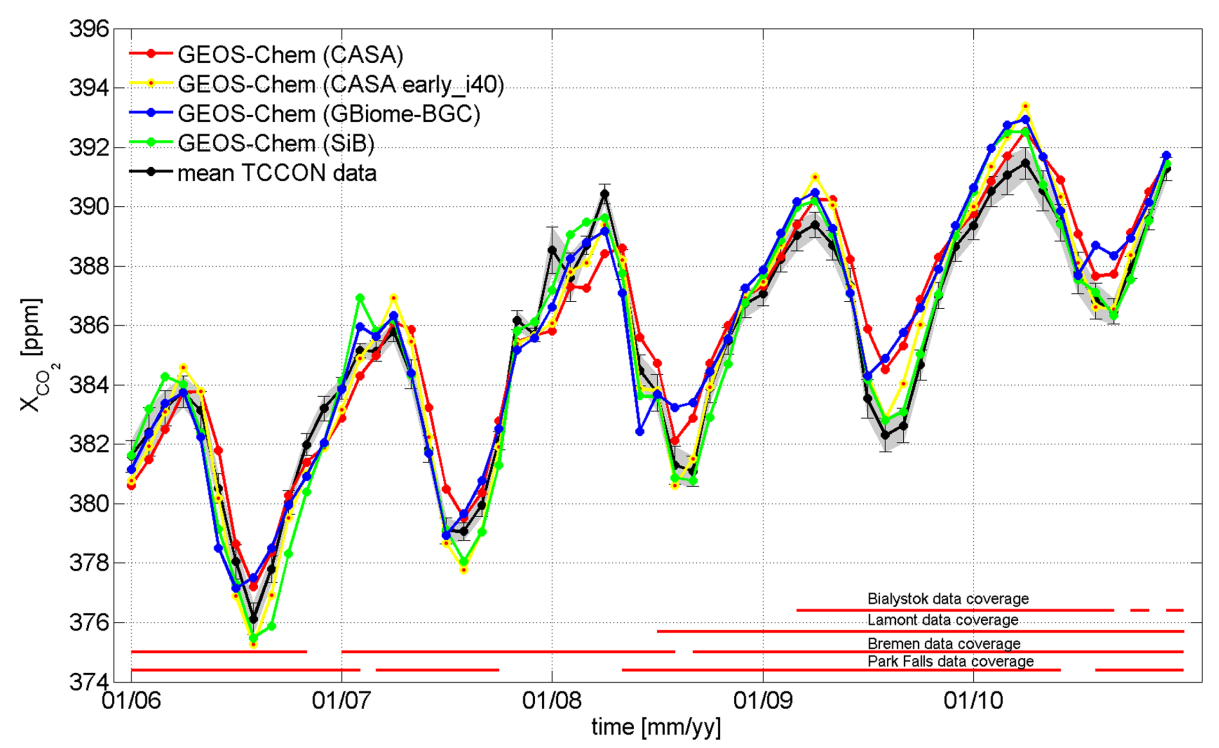

Fig. 2. The time series of the monthly averages of column averaged $\mathrm{X}_{\mathrm{CO}_{2}}$. The black line shows the mean for the TCCON measurements in Białystok (Poland), Bremen (Germany), Lamont (Oklahoma) and Park Falls (Wisconsin). The colored lines show the smoothed column averaged $\mathrm{CO}_{2}$ for the three models (CASA, $\mathrm{SiB}$, GBiome-BGC) and the manipulated CASA model (Sect. 7.2). The trend in the simulations is determined by the sum of the sources and sinks listed in Table 1 . For the comparison the daily averaged $\mathrm{GEOS}-\mathrm{Chem} \mathrm{CO}_{2}$ simulation profile for the same day was smoothed with the averaging kernel and a priori profile from the TCCON measurement and integrated to column averaged $\mathrm{X}_{\mathrm{CO}_{2}}$. In comparison with the TCCON measurements, the GEOS-Chem $\mathrm{CO}_{2}$ simulation with the SiB NEE input most closely simulates the seasonal cycle and the manipulated CASA model improves significantly the comparison. The variability of the TCCON time series in the winter of 2007-2008 is due to the few measurements averaged (Table S1 in the Supplement).

The seasonal amplitude differences are estimated by taking the ratio of the amplitude from the GEOS-Chem $\mathrm{CO}_{2}$ simulations and the amplitude measured by the TCCON instruments. The amplitude is calculated by the difference between the maximum and the minimum $\mathrm{X}_{\mathrm{CO}_{2}}$ in the seasonal cycle curve. Both CASA and GBiome-BGC simulate amplitudes that are too small by 15 and $12 \%$, respectively and the $\mathrm{SiB}$ simulation has a seasonal cycle that is too large by $9 \%$ (Table 3).

The GEOS-Chem $\mathrm{CO}_{2}$ simulation using the $\mathrm{SiB}$ model provides the best match to the measured seasonal cycle. The time delay in the $\mathrm{CO}_{2}$ drawdown is the shortest, at $-6 \pm 1$ days, and the cross correlation is maximized for the unshifted simulated seasonal cycle. The time delay of the $\mathrm{CO}_{2}$ release reveals a seasonal cycle minimum that is slightly too wide, but overall the seasonal amplitude matches the measurements well.

\subsection{GEOS-Chem $\mathrm{CO}_{2}$ simulation using manipulated CASA NEE estimations}

The comparison of the GEOS-Chem $\mathrm{CO}_{2}$ simulation using CASA NEE estimations with the TCCON measurements revealed a delay in the start of the growing season and a seasonal amplitude that was too small (Fig. 3). Here, the CASA NEE was amplified by $40 \%$ between $45^{\circ} \mathrm{N}$ and $65^{\circ} \mathrm{N}$ and the onset of the growing season was shifted earlier by adding the NEE in July to the NEE in May between $50^{\circ} \mathrm{N}$ and $6^{\circ} \mathrm{N}$, analogous to Keppel-Aleks et al. (2012). The resulting GEOS-Chem $\mathrm{CO}_{2}$ simulation was detrended by $1.081 \mathrm{Pg} \mathrm{y}^{-1}$ to account for the increased NEE uptake.

Figure 2 shows the monthly averages of the GEOS-Chem $\mathrm{CO}_{2}$ simulation using the manipulated CASA NEE estimations (CASA early_i40). The seasonal amplitude increased significantly and even overestimates the seasonal cycle amplitude measured by the TCCON sites. The onset of the growing season seems to be in agreement with the TCCON measurements. In order to quantify the changes, the data are analyzed in an analogous fashion to the analysis in Sect. 7.1 (Fig. 3). The seasonal amplitude is overestimated by a factor of 1.20. The onset and the time period of the growing season are estimated accurately, and the cross-correlation optimization yields an unchanged $\mathrm{CO}_{2}$ seasonal cycle. The calculation of the correlation coefficient improved from 0.954 to 0.963 for the manipulated CASA NEE input (Table 3).

These results are consistent with the findings of Randerson et al. (1997) and Keppel-Aleks et al. (2011): the NEE in the boreal forest has a large impact on the seasonal $\mathrm{CO}_{2}$ cycle amplitude and the onset time of the growing season determines the seasonal cycle phase at the four TC$\mathrm{CON}$ sites. Changes in these quantities significantly influence the seasonal cycle measured at single locations in the Northern Hemisphere. The TCCON data suggest that the 


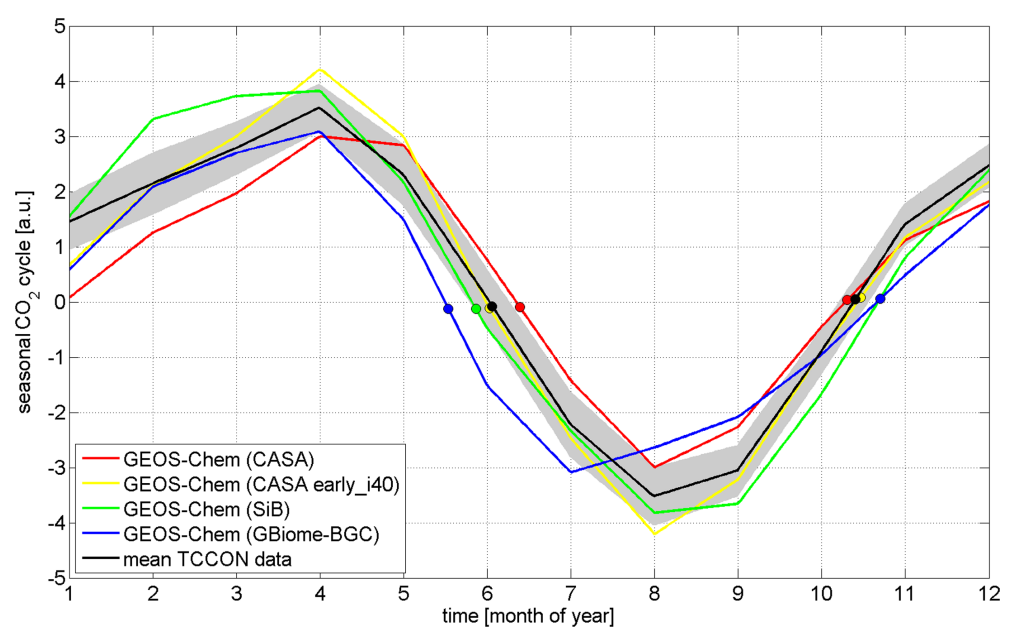

Fig. 3. Averaged seasonal cycles, derived with the averages of the monthly means, shown in Fig. 2. The emerging patterns reveal the characteristics already seen in the NEE inputs. The simulated $\mathrm{CO}_{2}$ drawdown using $\mathrm{SiB}$ or GBiome-BGC starts too early compared to the TCCON measurements and too late using CASA inputs. The seasonal amplitude is slightly overestimated with SiB and underestimated using GBiome-BGC and CASA. The simulated $\mathrm{CO}_{2}$ release starts too early using CASA and too late using SiB or GBiome-BGC. The zero crossings indicated with dots give an estimate of the delays in the $\mathrm{CO}_{2}$ drawdown and release (Table 3). The manipulated NEE CASA input leads to a significant improvement of the simulated $\mathrm{CO}_{2}$ cycle. Even though the seasonal amplitude is overestimated, the timing of the $\mathrm{CO}_{2}$ drawdown and $\mathrm{CO}_{2}$ release is estimated accurately (Sect. 7.2).

NEE distribution on large scales drives local variability in atmospheric total column $\mathrm{CO}_{2}$.

\subsection{Evaluation of dynamic NEE in SiB}

In order to quantify the difference between the year-specific NEE and the static SiB NEE, a simulation for 2006 through 2010 was calculated using the SiB NEE estimation for the year 2009. This approach gives a measure of the difference between the climatology and year-specific fluxes.

Figure 4 shows the spatial distribution of anomalies in the growing season net flux (average NEE from May-August) relative to the five-year climatological average. Interannual variability is clearly evident throughout North America, Europe, and Boreal Asia, with anomalies representing $10 \%$ or less of the climatological average. Figure 5 shows the monthly averages of the GEOS-Chem $\mathrm{CO}_{2}$ simulation using year-specific NEE estimations, as already depicted in Fig. 2, and the GEOS-Chem $\mathrm{CO}_{2}$ simulation using $\mathrm{SiB} 2009$ NEE estimations for the entire time period. Despite interannual variability in the spatial distribution of NEE, the anomalies tend to be weak or are canceled in the spatial average such that differences in seasonal cycles aggregated over high latitudes is small. The correlation coefficient between the simulations and the TCCON data are given with 0.971 for yearspecific SiB NEE estimates and 0.970 for SiB 2009 NEE estimations (Table 3). This finding shows that the year-specific NEE only slightly improves the agreement with the measured seasonal cycle, suggesting that the modeled $\mathrm{CO}_{2}$ seasonal cycle is mainly driven by the spatial flux distribution and vari- ability in atmospheric dynamics. A further analysis of the interannual dynamics will be forthcoming.

GEOS-Chem $\mathrm{CO}_{2}$ simulations using year-specific $\mathrm{SiB}$ NEE estimations or only SiB 2009 NEE estimations are a significant improvement compared to simulations with the standard CASA climatology, currently used within the GEOSChem simulation. To illustrate the differences between the standard CASA climatology and the $\mathrm{SiB}$ yearly values, we compare the GEOS-Chem $\mathrm{CO}_{2}$ simulations to the individual TCCON time series. In Fig. 6 the weekly averaged TCCON $\mathrm{X}_{\mathrm{CO}_{2}}$ time series at the four TCCON sites used in this study, Park Falls (Wisconsin), Lamont (Oklahoma), Bremen (Germany), and Białystok (Poland) are compared with the weekly averaged GEOS-Chem $\mathrm{CO}_{2}$ simulations using CASA and $\mathrm{SiB}$ NEE. The seasonal cycle of the GEOS-Chem $\mathrm{CO}_{2}$ simulations using $\mathrm{SiB}$ estimations fits the data best when comparing the measured and modeled seasonal cycle amplitude and phase. The GEOS-Chem $\mathrm{CO}_{2}$ simulations using CASA inputs tend to underestimate the $\mathrm{CO}_{2}$ abundance, especially in the seasonal cycle minimum, and the seasonal cycle phase is often delayed compared to the TCCON measurements.

\subsection{Analysis of the differences between CASA and SiB NEE estimates}

Here, we examine possible causes of delayed drawdown in CASA. On monthly time scales, NEE represents a small difference in large but opposing carbon fluxes. Fluxes to the atmosphere are caused by heterotrophic respiration $(\mathrm{RH})$ in the soil and autotrophic respiration (RA) by vegetation; these fluxes can by lumped together and defined as RE. Fluxes 

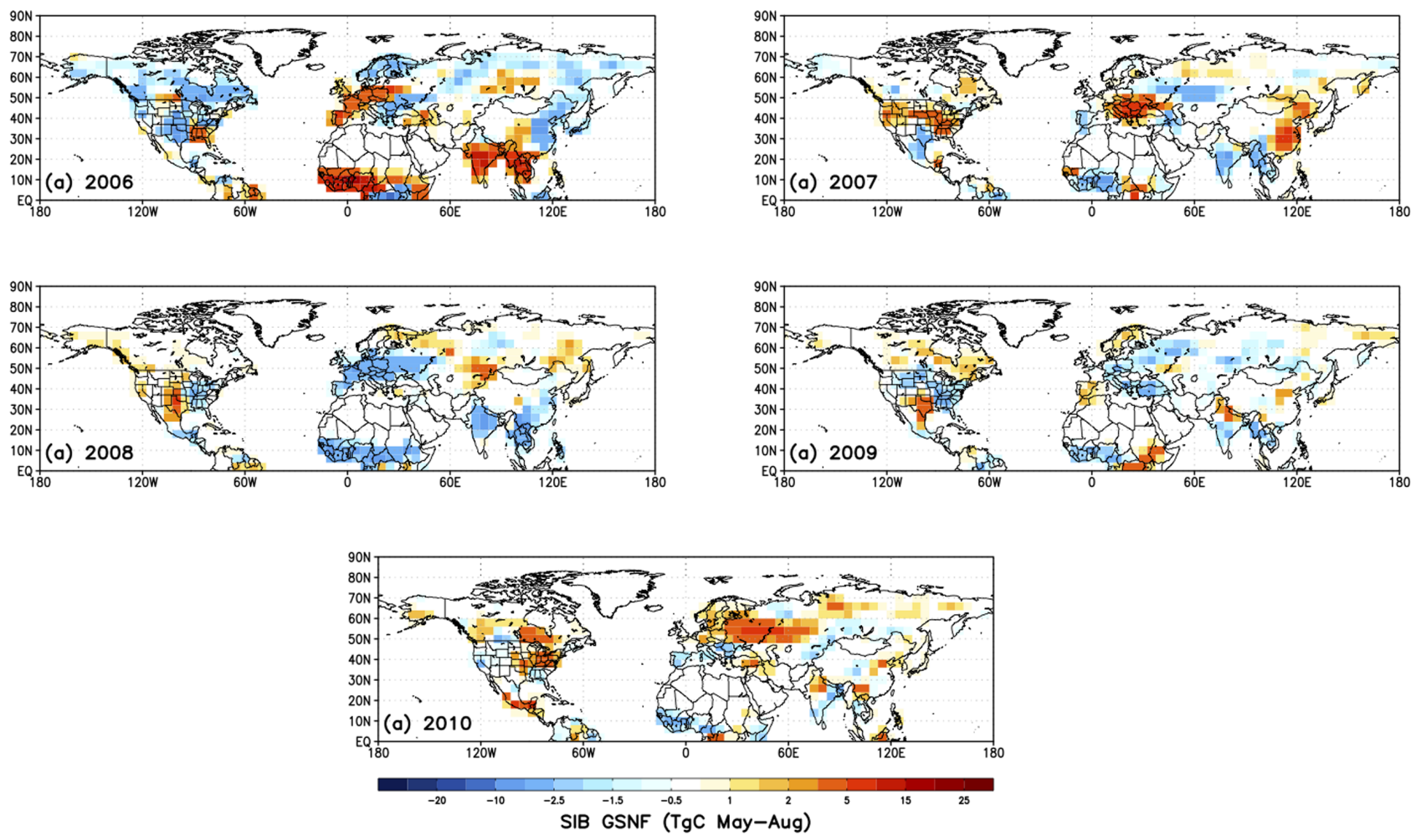

Fig. 4. Spatial distribution of annual anomalies in growing season net flux (average SiB NEE from May-August), representing the difference of annual mean GSNF from the five-year climatological average for (a) 2006, (b) 2007, (c) 2008, (d) 2009, and (e) 2010. Interannual variability is clearly evident throughout North America, Europe, and Boreal Asia, with anomalies representing $10 \%$ or less of the climatological average.

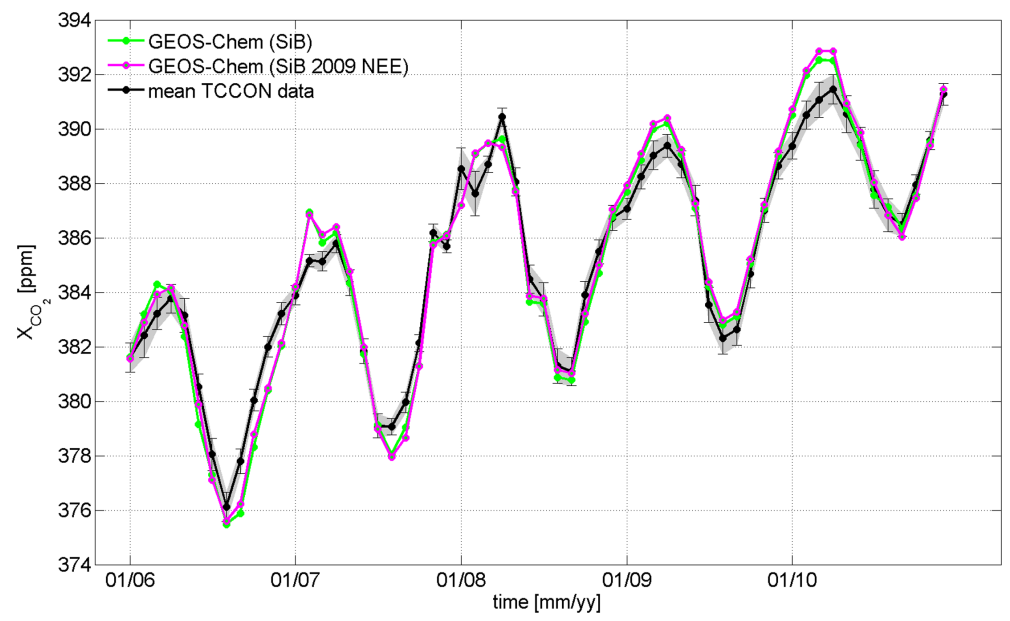

Fig. 5. The same as in Fig. 2, showing the monthly mean $\mathrm{X}_{\mathrm{CO}_{2}}$ for the GEOS-Chem $\mathrm{CO}_{2}$ simulation using year-specific SiB fluxes and using only SiB 2009 NEE estimations for the whole time period. The differences between these GEOS-Chem $\mathrm{CO}_{2}$ simulations give a measure of the impact of year-specific SiB NEE fluxes in contrast to the climatology, showing only slight differences. The variability of the TCCON time series in the winter of 2007-2008 is due to the few measurements averaged (Table S1 in the Supplement).

from the atmosphere are caused by gross photosynthetic uptake by canopy vegetation, and is typically referred to as GPP. NEE can then be defined as RE - GPP. In high latitude regions such as boreal forests, RE tends to exceed GPP during winter months, causing a net flux to the atmosphere, while
GPP exceeds RE during the summer, causing net carbon flux into the terrestrial biosphere. The amplitude of seasonal NEE is therefore determined by differences in the magnitudes of GPP and RE, while the timing of drawdown is determined 

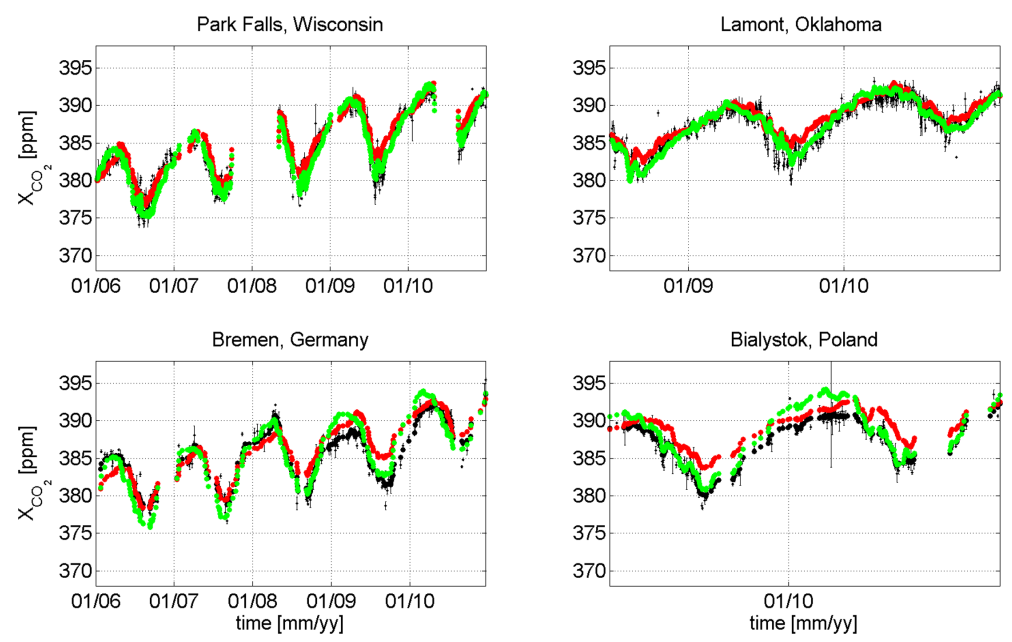

Fig. 6. Weekly averaged GEOS-Chem $\mathrm{CO}_{2}$ simulations using CASA NEE estimations (red dots) and SiB NEE inputs (green dots) in comparison with weekly averaged TCCON measurements at four sites: Park Falls (Wisconsin), Lamont (Oklahoma), Bremen (Germany), Białystok (Poland).

by phase differences. We can therefore use GPP and RE to understand why the drawdown is delayed in CASA.

Unfortunately, GPP and RE are not available for the climatological CASA fluxes typically used as the GEOS-Chem prior (Olsen and Randerson, 2004). For the purpose of examining delayed drawdown in this section, we therefore examine CASA-GFED3 as a proxy for CASA. CASA-GFED3 is described in van der Werf (2010). Both versions of CASA are light use efficiency models in which NPP, which represents GPP - RA, is calculated from satellite-derived estimates of the fraction of available photosynthetically active radiation (fAPAR). The primary difference is that CASA-GFED3 uses MODIS radiative transfer algorithms for calculating fAPAR while CASA uses NDVI observations from AVHRR. Both versions also use similar models to predict heterotrophic respiration from soil carbon pools, where living biomass is transferred to litter pools and subsequently decomposed at rates depending on temperature and soil moisture.

NPP and RH data were collected from the database (www. globalfiredata.org/Data/index.html) on 24 October 2012. NPP and RH need to be converted to GPP and RE, respectively, for comparison to $\mathrm{SiB}$, which estimates GPP directly and solves for RE as a function of soil moisture and temperature, scaled to balance GPP annually. For CASA-GFED3 we assume GPP can be approximated as $2 \times$ NPP (Prentice, 2001), and then solve for RE as NEE + GPP. All available carbon fluxes for $\mathrm{SiB}, \mathrm{CASA}$ and CASA-GFED3 are shown in Fig. 7, where $\mathrm{SiB}$ and CASA-GFED 3 are $5 \mathrm{yr}$ averages and CASA is 1 yr. CASA and CASA-GFED3 have very similar timing and comparable amplitudes of seasonal NEE, with a smaller CASA-GFED3 NEE amplitude than CASA.

$\mathrm{SiB}$ and CASA-GFED3 have very similar patterns of GPP, including phase and amplitude. This is likely due to the fact that both models are driven by MODIS phenology. Patterns

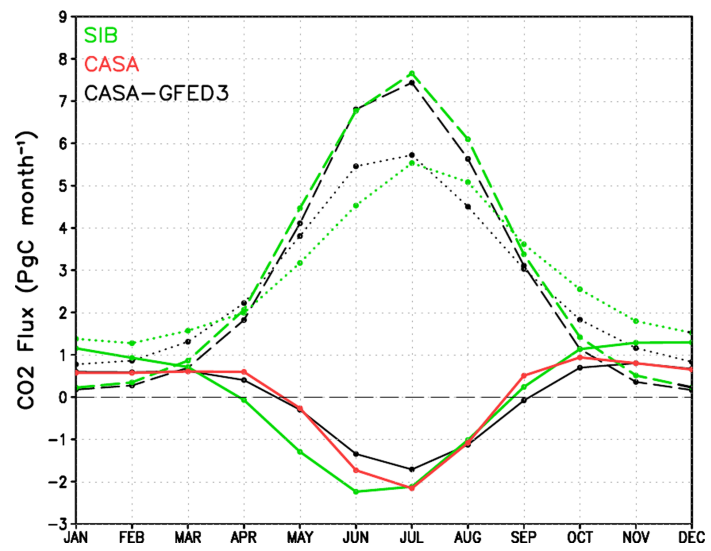

Fig. 7. Seasonal cycles of NEE (solid), gross primary production (GPP, dashed, positive represents influx into the plant canopy), and ecosystem respiration (RE, dotted, positive represents influx into the atmosphere) aggregated from $30-75^{\circ} \mathrm{N}$ and averaged from 2006 2010. Flux estimates are for SIB (green), CASA (red, NEE only) and CASA-GFED3 (black). The timing and magnitude of GPP is approximately the same for both models, which means the difference in the timing of drawdown is likely due to RE, which is delayed by roughly one month in SIB relative to CASA-GFED3.

of $\mathrm{RE}$ are, however, different, with $\mathrm{SiB}$ shifted later in time $(\approx 1$ month) relative to CASA-GFED3. Peak fluxes due to $\mathrm{RE}$ and GPP therefore tend to be more in phase in CASAGFED3 and out of phase in $\mathrm{SiB}$. As a result of delayed RE, the greatest imbalance between RE and GPP occurs early in the growing season, causing early spring drawdown and slightly earlier leaf senescence in $\mathrm{SiB}$. This finding is consistent with the improvement seen for the simulation using the shifted onset of the growing season in CASA in Sect. 7.2. The delayed drawdown by one month seen in the comparison 
with the TCCON data are like caused by the early onset of the RE.

Flux tower measurements of seasonal carbon exchange tend to support $\mathrm{SiB}$, with RE delayed relative to GPP in temperate deciduous and boreal coniferous forests (Falge, 2002). Seasonal patterns of RE are mainly controlled by temperature (Griffis, 2004, and references therein) while GPP is strongly dependent on light. Over the season light and temperature are out of phase, with peak temperature delayed relative to peak radiation yielding the out-of-phase relationship between GPP and RE at high latitudes.

\section{Conclusions}

We evaluated three estimations of biosphere fluxes within the chemical transport model GEOS-Chem. Errors in the global $\mathrm{CO}_{2}$ distribution are evaluated through comparison with TC$\mathrm{CON}$ measurements. The standard GEOS-Chem $\mathrm{CO}_{2}$ simulation (Nassar et al., 2010) uses climatological CASA NEE to estimate the balanced atmosphere-biosphere exchange. However, we show that the estimate of the $\mathrm{CO}_{2}$ uptake in the growing season in the boreal forest is underestimated and that the onset of the growing season is delayed using this estimate of biospheric fluxes. By enhancing the $\mathrm{CO}_{2}$ uptake in the boreal forest and shifting the onset of the growing season earlier, the comparison with TCCON data is significantly improved. Similar to CASA, GBiome-BGC also underestimates the $\mathrm{CO}_{2}$ uptake in the growing season. $\mathrm{SiB}$ shows reasonably good agreement in comparison with the TCCON data, primarily derived from the phasing of respiration with respect to gross primary production.

Large-scale errors in the estimates are identified through a comparison with TCCON data and the $\mathrm{CO}_{2}$ simulations are highly dependent on the choice of the atmosphere-biosphere model. We show that an accurate estimation of carbon fluxes is crucial for the correct simulation of the seasonal carbon cycle. In general, this means that large-scale errors must be carefully evaluated before retrieving local fluxes. Variations in the total column are an useful validation resource for diagnosing errors on hemispheric scale.

\section{Supplementary material related to this article is available online at: http://www.atmos-chem-phys.net/13/ 5103/2013/acp-13-5103-2013-supplement.pdf.}

Acknowledgements. We thank Ray Nassar (Environment Canada) for his helpful support and committed discussions. This analysis was supported by a sub-contract from University of California, Irvine (NASA NNX10AT83G, James Randerson, PI). For the TCCON sites at Białystok (Poland), we acknowledge financial support by the Senate of Bremen and the EU projects IMECC and GEOmon as well as maintainance and logistical work provided by AeroMeteo Service (Białystok). Support for the US TCCON operations is provided by NASA's Carbon Cycle Program grant NNX11AG016 for Park Falls (Wisconsin), and NASA's ACOS/OCO-2 project for Lamont (Oklahoma). The simulations used in this study were performed on the Caltech Division of Geological and Planetary Sciences Dell Cluster. GBIOME-BGCv1 is provided by the Max-Planck Institute for Biogeochemistry, Germany. MPI assumes no responsibility for the proper use of GBIOME-BGC by others.

Edited by: J. Pongratz

\section{References}

Andres, R. J., Marland, G., Fung, I., and Matthews, E.: A $1 \times 1$ distribution of carbon dioxide emissions from fossil fuel consumption and cement manufacture, 1950-1990, Global Biogeochem. Cy., 10, 419-429, doi:10.1029/96GB01523, 1996.

Baker, D. F., Law, R. M., Gurney, K. R., Rayner, P., Peylin, P., Denning, A. S., Bousquet, P., Bruhwiler, L., Chen, Y.-H., Ciais, P., Fung, I. Y., Heimann, M., John, J., Maki, T., Maksyutov, S., Masarie, K., Prather, M., Pak, B., Taguchi, S., and Zhu, Z.: TransCom 3 inversion intercomparison: Impact of transport model errors on the interannual variability of regional $\mathrm{CO}_{2}$ fluxes, 1988-2003, Global Biogeochem. Cy., 20, GB1002, doi:10.1029/2004GB002439, 2006.

Baker, I. T., Denning, A. S., Hanan, N., Vidale, P.-L., Davis, K., and Bakwin, P.: Simulated and observed fluxes of sensible and latent heat and $\mathrm{CO}_{2}$ at the WLEF-TV Tower using SiB2.5, Global Change Biol., 9, 1262-1277, 2003.

Baker, I. T., Denning, A. S., and Stöckli, R.: North American gross primary productivity: regional characterization and interannual variability, Tellus B, 62, 533-549, doi:10.1111/j.16000889.2010.00492.x, 2010.

Barkley, M. P., Monks, P. S., Hewitt, A. J., Machida, T., Desai, A., Vinnichenko, N., Nakazawa, T., Yu Arshinov, M., Fedoseev, N., and Watai, T.: Assessing the near surface sensitivity of SCIAMACHY atmospheric $\mathrm{CO}_{2}$ retrieved using (FSI) WFM-DOAS, Atmos. Chem. Phys., 7, 3597-3619, doi:10.5194/acp-7-35972007, 2007.

Bey, I., Jacob, D. J., Yantosca, R. M., Logan, J. A., Field, B., Fiore, A. M., Li, Q., Liu, H., Mickley, L. J., and Schultz, M.: Global modeling of tropospheric chemistry with assimilated meteorology: Model description and evaluation, J. Geophys. Res., 106, 23073-23096, 2001.

Boden, T., Marland, G., and Andres, R.: Global, Regional, and National Fossil-Fuel $\mathrm{CO}_{2}$ Emissions, Tech. rep., Carbon Dioxide Information Analysis Center, Oak Ridge National Laboratory, US Department of Energy, Oak Ridge, Tenn., USA, doi:10.3334/CDIAC/00001, 2009.

Buchwitz, M., de Beek, R., Noël, S., Burrows, J. P., Bovensmann, H., Schneising, O., Khlystova, I., Bruns, M., Bremer, H., Bergamaschi, P., Körner, S., and Heimann, M.: Atmospheric carbon gases retrieved from SCIAMACHY by WFM-DOAS: version $0.5 \mathrm{CO}$ and $\mathrm{CH}_{4}$ and impact of calibration improvements on $\mathrm{CO}_{2}$ retrieval, Atmos. Chem. Phys., 6, 2727-2751, doi:10.5194/acp6-2727-2006, 2006.

Butz, A., Guerlet, S., Hasekamp, O., Schepers, D., Galli, A., Aben, I., Frankenberg, C., Hartmann, J., Tran, H., Kuze, A., KeppelAleks, G., Toon, G., Wunch, D., Wennberg, P., Deutscher, N., Griffith, D., Macatangay, R., Messerschmidt, J., Notholt, 
J., and Warneke, T.: Toward accurate $\mathrm{CO}_{2}$ and $\mathrm{CH}_{4}$ observations from GOSAT, Geophys. Res. Lett., 38, L14812, doi:10.1029/2011GL047888, 2011.f

Chevallier, F., Deutscher, N. M., Conway, T. J., Ciais, P., Ciattaglia, L., Dohe, S., Fröhlich, M., Gomez-Pelaez, A. J., Griffith, D. W. T., Hase, F., Haszpra, L., Krummel, P., Kyrö, E., Labuschagne, C., Langenfelds, R., Machida, T., Maignan, F., Matsueda, H., Morino, I., Notholt, J., Ramonet, M., Sawa, Y., Schmidt, M., Sherlock, V., Steele, P., Strong, K., Sussmann, R., Wennberg, P. O., Wofsy, S. C., Worthy, D., Wunch, D., and Zimnoch, M.: Global $\mathrm{CO}_{2}$ fluxes inferred from surface air-sample measurements and from TCCON retrievals of the $\mathrm{CO}_{2}$ total column, Geophys. Res. Lett., 38, 1-5, doi:10.1029/2011GL049899, 2011.

Corbett, J. J. and Koehler, H. W.: Updated emissions from ocean shipping, J. Geophys. Res., 108, 4650, doi:10.1029/2003JD003751, 2003.

Corbett, J. J. and Koehler, H. W.: Considering alternative input parameters in an activity-based ship fuel consumption and emissions model: Reply to comment by Endresen et al. on "Updated emissions from ocean shipping”, J. Geophys. Res., 109, D23303, doi:10.1029/2004JD005030, 2004.

Denning, A. S., Collatz, G. J., Zhang, C., Randall, D. A., Berry, J. A., Sellers, P. J., and Colello, G. D.and Dazlich, D. A.: Simulations of terrestrial carbon metabolism and atmospheric $\mathrm{CO}_{2}$ in a general circulation model, Part 1: Surface carbon fluxes, Tellus B, 48, 521-542, 1996.

Deutscher, N. M., Griffith, D. W. T., Bryant, G. W., Wennberg, P. O., Toon, G. C., Washenfelder, R. A., Keppel-Aleks, G., Wunch, D., Yavin, Y., Allen, N. T., Blavier, J.-F., Jiménez, R., Daube, B. C., Bright, A. V., Matross, D. M., Wofsy, S. C., and Park, S.: Total column $\mathrm{CO}_{2}$ measurements at Darwin, Australia - site description and calibration against in situ aircraft profiles, Atmos. Meas. Tech., 3, 947-958, doi:10.5194/amt-3-947-2010, 2010.

Endresen, O., Sorgard, E., Behrens, H. L., Brett, P. O., and Isaksen, I. S. A.: A historical reconstruction of ships' fuel consumption and emissions, J. Geophys. Res., 112, D12301, doi:10.1029/2006JD007630, 2007.

Falge, E. A.: Seasonality of ecosystem respiration and gross primary production as derived from FLUXNET measurements, Agr. Forest Meteorol., 113, 53-74, 2002.

FLUXNET: http://fluxnet.ornl.gov/, last access: 10.05.2013, 2013.

Gaudinski, J. B., Trumbore, S., Davidson, E., and Zheng, S.: Soil carbon cycling in a temperate forest: Radiocarbon-based estimated of residence times, sequestration rates and partitioning of fluxes, Biogeochemistry, 51, 33-69, 2000.

Geibel, M. C., Gerbig, C., and Feist, D. G.: A new fully automated FTIR system for total column measurements of greenhouse gases, Atmos. Meas. Tech., 3, 1363-1375, doi:10.5194/amt-31363-2010, 2010.

Goodale, C. L., Apps, M. J., Birdsey, R. A., Field, C. B., Heath, L. S., Houghton, R. A., Jenkins, J. C., Kohlmaier, G. H., Kurz, W., Liu, S., Nabuurs, G.-J., Nilsson, S., and Shvidenko, A. Z.: Forest Carbon sinks in the northern hemisphere, Ecol. Appl., 12, 891-899, doi:10.1890/10510761(2002)012[0891:FCSITN]2.0.CO;2, 2002.

Griffis, E. A.: Seasonal variation and partitioning of ecosystem respiration in a southern boreal aspen forest, Agr. Forest Meteorol., 125, 207-223, 2004.
Kalnay, E., Kanamitsu, M., Kistler, R., Collins, W., Deaven, D., Gandin, L., Iredell, M., Saha, S., White, G., Woollen, J., Zhu, Y., Leetmaa, A., Reynolds, R., Chelliah, M., Ebisuzaki, W., Higgins, W., Janowiak, J., Mo, K. C., Ropelewski, C., Wang, J., Jenne, R., and Joseph, D.: The NCEP/NCAR 40-Year Reanalysis Project, B. Am. Meteorol. Soc., 77, 437-471, doi:10.1175/15200477(1996)077<0437:TNYRP>2.0.CO;2, 1996.

Keppel-Aleks, G., Wennberg, P. O., and Schneider, T.: Sources of variations in total column carbon dioxide, Atmos. Chem. Phys., 11, 3581-3593, doi:10.5194/acp-11-3581-2011, 2011.

Keppel-Aleks, G., Wennberg, P. O., Washenfelder, R. A., Wunch, D., Schneider, T., Toon, G. C., Andres, R. J., Blavier, J.-F., Connor, B., Davis, K. J., Desai, A. R., Messerschmidt, J., Notholt, J., Roehl, C. M., Sherlock, V., Stephens, B. B., Vay, S. A., and Wofsy, S. C.: The imprint of surface fluxes and transport on variations in total column carbon dioxide, Biogeosciences, 9, 875891, doi:10.5194/bg-9-875-2012, 2012.

Kim, B. Y., Fleming, G., Balasubramanian, S., Malwitz, A., Klima, K., Locke, M., Holsclaw, C. A., Maurice, L. Q., and Gupta, M. L.: System for assessing Aviations Global Emissions (SAGE) Version 1.5 global Aviation Emissions Inventories for 20002004, Tech. Rep., US Department of Transportation Federal Aviation Administration (FAA), Office of Environment and Energy (AEE), 800 Independence Avenue, SW, Washington, DC 20591, 2005.

Kim, B. Y., Fleming, G., Lee, J. J., Waitz, I. A., Clarke, J.-P., Balasubramanian, S., Malwitz, A., Klima, K., Locke, M., Holsclaw, C. A., Maurice, L. Q., and Gupta, M. L.: System for assessing Aviations Global Emissions (SAGE), Part 1: Model description and inventory results, Transport. Res. D, 12, 325-346, doi:10.1016/j.trd.2007.03.007, 2007.

Le Quere, C., Raupach, M. R., Canadell, J. G., and Marland, G.: Trends in the sources and sinks of carbon dioxide, Nat. Geosci., 2, 831-836, doi:10.1038/ngeo689, 2009.

Messerschmidt, J., Macatangay, R., Notholt, J., Petri, C., Warneke, T., and Weinzierl, C.: Side by side measurements of $\mathrm{CO}_{2}$ by ground-based Fourier transform spectrometry (FTS), Tellus B, 62, 749-758, doi:10.1111/j.1600-0889.2010.00491.x, 2010.

Messerschmidt, J., Geibel, M. C., Blumenstock, T., Chen, H., Deutscher, N. M., Engel, A., Feist, D. G., Gerbig, C., Gisi, M., Hase, F., Katrynski, K., Kolle, O., Lavrič, J. V., Notholt, J., Palm, M., Ramonet, M., Rettinger, M., Schmidt, M., Sussmann, R., Toon, G. C., Truong, F., Warneke, T., Wennberg, P. O., Wunch, D., and Xueref-Remy, I.: Calibration of TCCON column-averaged $\mathrm{CO}_{2}$ : the first aircraft campaign over European TCCON sites, Atmos. Chem. Phys., 11, 10765-10777, doi:10.5194/acp-11-10765-2011, 2011.

Messerschmidt, J., Chen, H., Deutscher, N. M., Gerbig, C., Grupe, P., Katrynski, K., Koch, F.-T., Lavric, J. V., Notholt, J., Rödenbeck, C., Ruhe, W., Warneke, T., and Weinzierl, C.: Automated ground-based remote sensing measurements of greenhouse gases at the Bialystok site in comparison with collocated in situ measurements and model data, Atmos. Chem. Phys., 12, 6741-6755, doi:10.5194/acp-12-6741-2012, 2012.

Michalak, A. M., Bruhwiler, L., and Tans, P. P.: A geostatistical approach to surface flux estimation of atmospheric trace gases, J. Geophys. Res., 109, D14109, doi:10.1029/2003JD004422, 2004.

Morino, I., Uchino, O., Inoue, M., Yoshida, Y., Yokota, T., Wennberg, P. O., Toon, G. C., Wunch, D., Roehl, C. M., Notholt, 
J., Warneke, T., Messerschmidt, J., Griffith, D. W. T., Deutscher, N. M., Sherlock, V., Connor, B., Robinson, J., Sussmann, R., and Rettinger, M.: Preliminary validation of column-averaged volume mixing ratios of carbon dioxide and methane retrieved from GOSAT short-wavelength infrared spectra, Atmos. Meas. Tech., 4, 1061-1076, doi:10.5194/amt-4-1061-2011, 2011.

Nassar, R., Jones, D. B. A., Suntharalingam, P., Chen, J. M., Andres, R. J., Wecht, K. J., Yantosca, R. M., Kulawik, S. S., Bowman, K. W., Worden, J. R., Machida, T., and Matsueda, H.: Modeling global atmospheric $\mathrm{CO}_{2}$ with improved emission inventories and $\mathrm{CO}_{2}$ production from the oxidation of other carbon species, Geosci. Model Dev., 3, 689-716, doi:10.5194/gmd-3-689-2010, 2010.

Olsen, S. C. and Randerson, J. T.: Differences between surface and column atmospheric $\mathrm{CO}_{2}$ and implications for carbon cycle research, J. Geophys. Res., 109, D02301, doi:10.1029/2003JD003968, 2004.

Parazoo, N. C., Denning, A. S., Kawa, S. R., Corbin, K. D., Lokupitiya, R. S., and Baker, I. T.: Mechanisms for synoptic variations of atmospheric $\mathrm{CO}_{2}$ in North America, South America and Europe, Atmos. Chem. Phys., 8, 7239-7254, doi:10.5194/acp-87239-2008, 2008.

Peters, W., Jacobson, A. R., Sweeney, C., Andrews, A. E., Conway, T. J., Masarie, K., Miller, J. B., Bruhwiler, L. M. P., Pétron, G., Hirsch, A. I., Worthy, D. E. J., van der Werf, G. R., Randerson, J. T., Wennberg, P. O., Krol, M. C., and Tans, P. P.: An atmospheric perspective on North American carbon dioxide exchange: CarbonTracker, P. Natl. Acad. Sci., 104, 18925-18930, 2007.

Potter, C. S., Randerson, J. T., Field, C. B., Matson, P. A., Vitousek, P. M., Mooney, H. A., and Klooster, S. A.: Terrestrial ecosystem production: A process model based on global satellite and surface data, Global Biogeochem. Cy., 7, 811-841, doi:10.1029/93GB02725, 1993.

Prentice, I. C. E. A.: Contribution of Working Group 1 to the Third Assessment Report of the Intergovernmental Panel on Climate Change, in: chap. Climate Change 2001: The Scientific Basis, edited by: Houghton, J. T., Ding, Y., Griggs, D. J., Noguer, M., van der Linden, P. J., Dai, X., Maskell, K., and Johnson, C. A., 183-237, 2001.

Randerson, J. T., Thompson, M. V., Conway, T. J., Fung, I. Y., and Field, C. B.: The contribution of terrestrial sources and sinks to trends in the seasonal cycle of atmospheric carbon dioxide, Global Biogeochem. Cy., 11, 535-560, doi:10.1029/97GB02268, 1997.

Rayner, P. J. and O'Brien, D. M.: The utility of remotely sensed $\mathrm{CO} 2$ concentration data in surface source inversions, Geophys. Res. Lett., 28, 175-178, doi:10.1029/2000GL011912, 2001.

Reuter, M., Bovensmann, H., Buchwitz, M., Burrows, J. P., Connor, B. J., Deutscher, N. M., Griffith, D. W. T., Heymann, J., Keppel-Aleks, G., Messerschmidt, J., Notholt, J., Petri, C., Robinson, J., Schneising, O., Sherlock, V., Velazco, V., Warneke, T., Wennberg, P. O., and Wunch, D.: Retrieval of atmospheric $\mathrm{CO}_{2}$ with enhanced accuracy and precision from SCIAMACHY: Validation with FTS measurements and comparison with model results, J. Geophys. Res., 116, D04301, doi:10.1029/2010JD015047, 2011.

Rienecker, M. M., Suarez, M. J., Gelaro, R., Todling, R., Bachmeister, J., Liu, E., Bosilovich, M. G., Schubert, S. D., Takacs, L.,
Kim, G.-K., Bloom, S., Chen, J., Collins, D., Conaty, A., Silva, A. da, Gu, W., Joiner, J., Koster, R. D., Lucchesi, R., Molod, A., Owens, T., Pawson, S., Pegion, P., Redder, C. R., Reichle, R., Robertson, F. R., Ruddick, A. G., Sienkiewicz, M., and Woollen, J.: MERRA: NASA Modern-Era Retrospective Analysis for Research and Applications, J. Climate, 24, 3624-3648, 2011.

Rödenbeck, C.: Estimating $\mathrm{CO}_{2}$ sources and sinks from atmospheric mixing ratio measurements using a global inversion of atmospheric transport, Technical report 6, Max Planck Institute for Biogeochemistry, Jena, 2005.

Sausen, R. and Schumann, U.: Estimates of the Climate Response to Aircraft $\mathrm{CO}_{2}$ and $\mathrm{NO}_{\mathrm{x}}$ Emissions Scenarios, Climatic Change, 44, 27-58, 2000.

Schneising, O., Bergamaschi, P., Bovensmann, H., Buchwitz, M., Burrows, J. P., Deutscher, N. M., Griffith, D. W. T., Heymann, J., Macatangay, R., Messerschmidt, J., Notholt, J., Rettinger, M., Reuter, M., Sussmann, R., Velazco, V. A., Warneke, T., Wennberg, P. O., and Wunch, D.: Atmospheric greenhouse gases retrieved from S CIAMACHY: comparison to ground-based FTS measurements and model results, Atmos. Chem. Phys., 12, 1527-1540, doi:10.5194/acp-12-1527-2012, 2012.

Sellers, P. J., Mintz, Y., Sud, Y. C., and Dalcher, A.: A simple biosphere model (sib) for use within general circulation models, J. Atmos. Sci., 43, 505-531, 1986.

Sellers, P. J., Randall, D. A., Collatz, G. J., Berry, J. A., Field, C. B., Dazlich, D. A., Zhang, C., Colello, G. D., and Bounoua, L.: A revised land surface parameterization $(\mathrm{SiB} 2)$ for atmospheric GCMs, Part I: Model formulation, J. Climate, 9, 676-705, 1996.

Takahashi, T., Sutherland, S. C., Wanninkhof, R., Sweeney, C., Feely, R. A., Chipman, D. W., Hales, B., Friederich, G., Chavez, F., Sabine, C., Watson, A., Bakker, D. C., Schuster, U., Metzl, N., Yoshikawa-Inoue, H., Ishii, M., Midorikawa, T., Nojiri, Y., Körtzinger, A., Steinhoff, T., Hoppema, M., Olafsson, J., Arnarson, T. S., Tilbrook, B., Johannessen, T., Olsen, A., Bellerby, R., Wong, C., Delille, B., Bates, N., and de Baar, H. J.: Climatological mean and decadal change in surface ocean $p \mathrm{CO}_{2}$, and net sea-air $\mathrm{CO}_{2}$ flux over the global oceans, Deep-Sea Res. Pt. II, 56, 554-577, doi:10.1016/j.dsr2.2008.12.009, 2009.

Trusilova, K. and Churkina, G.: The terrestrial ecosystem model GBIOME-BGCv1, Technical Reports - 14, Tech. Rep., MaxPlanck-Institut für Biogeochemie, P.O. Box 100164, 07701 Jena, Germany, 2008.

van der Werf, G. R., Randerson, J. T., Giglio, L., Collatz, G. J., Mu, M., Kasibhatla, P. S., Morton, D. C., DeFries, R. S., Jin, Y., and van Leeuwen, T. T.: Global fire emissions and the contribution of deforestation, savanna, forest, agricultural, and peat fires (19972009), Atmos. Chem. Phys., 10, 11707-11735, doi:10.5194/acp10-11707-2010, 2010.

Wang, C., Corbett, J., and Firestone, J.: Modeling Energy Use and Emissions from North American Shipping: Application of the Ship Traffic, Energy, and Environment Model, Environ. Sci. Technol., 41, 3226-3232, doi:10.1021/es060752e, 2007.

Washenfelder, R., Toon, G., Blavier, J.-F., Yang, Z., Allen, N., Wennberg, P., Vay, S., Matross, D., and Daube, B.: Carbon dioxide column abundances at the Wisconsin Tall Tower site, J. Geophys. Res., 111, 1-11, doi:10.1029/2006JD007154, 2006.

Wilkerson, J. T., Jacobson, M. Z., Malwitz, A., Balasubramanian, S., Wayson, R., Fleming, G., Naiman, A. D., and Lele, S. K.: Analysis of emission data from global commercial 
aviation: 2004 and 2006, Atmos. Chem. Phys., 10, 6391-6408, doi:10.5194/acp-10-6391-2010, 2010.

Wunch, D., Toon, G. C., Wennberg, P. O., Wofsy, S. C., Stephens, B. B., Fischer, M. L., Uchino, O., Abshire, J. B., Bernath, P., Biraud, S. C., Blavier, J.-F. L., Boone, C., Bowman, K. P., Browell, E. V., Campos, T., Connor, B. J., Daube, B. C., Deutscher, N. M., Diao, M., Elkins, J. W., Gerbig, C., Gottlieb, E., Griffith, D. W. T., Hurst, D. F., Jiménez, R., Keppel-Aleks, G., Kort, E. A., Macatangay, R., Machida, T., Matsueda, H., Moore, F., Morino, I., Park, S., Robinson, J., Roehl, C. M., Sawa, Y., Sherlock, V., Sweeney, C., Tanaka, T., and Zondlo, M. A.: Calibration of the Total Carbon Column Observing Network using aircraft profile data, Atmos. Meas. Tech., 3, 1351-1362, doi:10.5194/amt3-1351-2010, 2010.

Wunch, D., Toon, G. C., Blavier, J.-F. L., Washenfelder, R. A., Notholt, J., Connor, B. J., Griffith, D. W. T., Sherlock, V., and Wennberg, P. O.: The Total Carbon Column Observing Network, Philos. T. Roy. Soc. A, 369, 2087-2112, doi:10.1098/rsta.2010.0240, 2011a.
Wunch, D., Wennberg, P. O., Toon, G. C., Connor, B. J., Fisher, B., Osterman, G. B., Frankenberg, C., Mandrake, L., O’Dell, C., Ahonen, P., Biraud, S. C., Castano, R., Cressie, N., Crisp, D., Deutscher, N. M., Eldering, A., Fisher, M. L., Griffith, D. W. T., Gunson, M., Heikkinen, P., Keppel-Aleks, G., Kyrö, E., Lindenmaier, R., Macatangay, R., Mendonca, J., Messerschmidt, J., Miller, C. E., Morino, I., Notholt, J., Oyafuso, F. A., Rettinger, M., Robinson, J., Roehl, C. M., Salawitch, R. J., Sherlock, V., Strong, K., Sussmann, R., Tanaka, T., Thompson, D. R., Uchino, O., Warneke, T., and Wofsy, S. C.: A method for evaluating bias in global measurements of $\mathrm{CO}_{2}$ total columns from space, Atmos. Chem. Phys., 11, 12317-12337, doi:10.5194/acp11-12317-2011, $2011 \mathrm{~b}$.

Yang, Z., Washenfelder, R., Keppel-Aleks, G., Krakauer, N., Randerson, J., Tans, P., Sweeney, C., and Wennberg, P.: New constraints on Northern Hemisphere growing season net flux, Geophys. Res. Lett., 34, L12807, doi:10.1029/2007GL029742, 2007.

Yevich, R. and Logan, J. A.: An assessment of biofuel use and burning of agricultural waste in the developing world, Global Biogeochem. Cy., 17, 1095, doi:10.1029/2002GB001952, 2003. 